\title{
We should've made a revolution: A critical rhapsody of the Hungarian education system's catching-up revolutions since 1989
}

Tamás Tóth, University of Lower Silesia, Wrocław, Poland

György Mészáros, Eötvös Loránd University, Budapest, Hungary

András Marton, Wesley János Kindergarten, Primary School, Vocational School, and High School, Budapest, Hungary

\begin{abstract}
From the perspective of the world-systems theory and post-colonial studies, the 1989 transition in Hungary was a part of the re-integration of former Soviet countries into an inferior position in the world system. The political-economic transition was in no sense a revolution, but a replacement of dictatorial/totalitarian state capitalism with neoliberal global capitalism. In this paper we will analyze how Hungary's semi-peripheral "catching-up revolution" consisted of stabilizing the neoliberal hegemony in education. As a result, one of the most decentralized, diverse, vertically, and horizontally stratified, and hence extremely selective education systems emerged from the gloomy Central-East European semi-periphery with exemplary diligence in conserving and reproducing social
\end{abstract}


inequalities. Some 27 years after the transition, the teaching staff from Herman Ottó High School in Budapest wrote a public letter analyzing the problems of public education and criticizing the Hungarian government's interventions, which led to one of the country's biggest movements since the political-economic transition in 1989. To understand the conditions that led to these situations, wherein education under siege triggered the biggest protests since 1989, we will first describe how the Hungarian education system was affected by the political-economic transition. Second, we will point to a rupture in the post-socialist history of Hungary, namely the neoconservative interventions of Hungary's post-fascist, far-right government which has been in power since 2010. And lastly, we will try to place the teacher's movement (and, briefly, the pro-Central European University protests) in this post-socialist rhapsody by showing how they interweave with Hungary's forever lasting semi-peripheral catching-up revolution. In our conclusion we will try to propose a strategy drawing on Immanuel Wallerstein's idea of an antisystemic Rainbow Coalition, by which new social and anti-systemic movements could organize their resistance more effectively.

\section{Keywords}

: Education policy, neoliberalism, neoconservatism, social movements, semi-periphery, post-socialist reforms 


\section{Sticks and stones}

Massive protests have emerged in Hungary since Parliament passed a law in April 2017 targeting one of the country's most prestigious and internationally recognized universities, the Central European University (CEU). The right-wing government (Fidesz) changed national law on higher education in an accelerated procedure, setting out conditions that put CEU's very existence at risk. The protesters decry the lack of negotiations and often refer to a May 1988 interview - an emotional outburst from the young Viktor Orbán (now prime minister) just a few weeks after Fidesz was established: The political system that is unwilling to negotiate with the organized forces of society can only blame itself when people shoot at it. It can only blame itself! And it is not those who shoot who should bear the burden of responsibility, but those who refused to negotiate with peaceful people. (Elbert et al., 1988)

The protesters' critique of the unilateral, top-down and antidemocratic processes was also characteristic of the teachers' movement, which emerged in January 2016 when the teaching staff of Herman Ottó High School (Miskolc) wrote a public letter analyzing the problems of public education and criticizing the Hungarian government's interventions. This open letter led to one of the country's biggest movements since the politicaleconomic transition of 1989. Teachers demanded decentralization of the system; suspension of reforms; civic and professional consensus; reduction of administration and bureaucracy; revision of the inspection system and teachers' career model; and radical reduction of content in the national curriculum. "We see the education system is now in 
danger," the teachers wrote. "It all became chaotic. Insecurity, despair, apathy reign in the teachers' rooms" (Herman Ottó Gimnázium, 2016).

To understand the conditions that led to these situations, in which education under siege triggered the biggest protests since 1989, we will first describe how the politicaleconomic transition affected the Hungarian education system. Second, we will point to a rupture in Hungary's post-socialist history; that is, the interventions of the post-fascist, far-right government that has been in power since 2010. Finally, we will try to place the teacher's movement (and briefly the pro-CEU protests) in this post-socialist rhapsody by showing how it interweaves with Hungary's endless semi-peripheral catching-up revolution (cf. Böröcz, 2012; Habermas, 1990). In our conclusion, we will propose a strategy, drawing on Wallerstein, through which new social and anti-systemic movements could organize more effective resistance.

\section{9 and Scrooge McDuck's gold}

On December 12, 1993, as many Hungarians who were 5-10 years old at the time remember, Hungarian Television went dark during a "Duck Tales" episode as the death of Prime Minister József Antall, who had led the first freely elected government after the transition in 1989, was announced (Jekel, 2010). This was the first time the children of the transition faced politics and the interplay between the glorious West and Hungary's gloomy semi-periphery. To understand this interplay, we will use Wallerstein's (1974, 1980) world-systems analysis as an approach that assumes every country operates to 
maximize profits, determined by the logic of accumulation of capital. This global framework refers to the transnational division of labor, which divides the world into core, semi-peripheral and peripheral countries, and outlines a series of power relations.

From the perspective of world-systems analysis and post-colonial studies, the 1989 transition in Hungary was a part of the re-integration of former socialist countries into an inferior position in the world system. Wallerstein (1983) argues that the socialist countries already had much in common with the capitalist world-system before 1989 - for example, the belief in linear progress of economic growth and development - and they were already, in a sense, part of the capitalist world-system even before the transitions. From this point of view, the "really-existing" socialism was a form of totalitarian state capitalism and had many features in common with the capitalist world-system, which was also based on "commodity production, wage work, social division of labor, labor subjected to capital, (...) the only missing element was market coordination, which was replaced with central planning [cf. planned economy]" (Tamás, 2008: 8). Wallerstein also argues that while Western conservatives celebrated the "watershed" of the transitions from 1989 to 1990 , they were actually a terrible challenge for the capitalist world-system. The socialist leaderships ensured people's faith in development and progress, and thus functioned as "stabilizing power because they sat on the adventurous leftism of the masses. Now when you remove these people from power, what you eliminate is the 
control that was sitting on the disgruntled masses on behalf of the capitalist system" (Wallerstein and Dunaway, 1999: 297).

Despite the interpretations that hold that Central-Eastern European transitions were built exclusively from outside, through the multinational influx of capital and knowledge, the history of the transitions was not written solely by either the nations in the semi-periphery or the core authorities, but by the interplay between them. The transition in Hungary was a top-down process on a national scale, conducted by the elite and by late-Kádárian technocracy. The technocracy successfully aligned with the North Atlantic vision of global neoliberal capitalism even before 1989 (Szigeti, 2010), exploiting the belief that the "experts" can "pursue 'development' more effectively than the indigenous bourgeoisie" (Wallerstein, 1976: 478). The late-Kádárian technocracy was already prepared - with the help of international economic-political backup - to convert their political, economic and cultural capital into global, international capital, and to push through the reforms necessary for this process (Bozóki and Szalai, 2010).

The overnight implementation of neoliberal stabilization and liberalization policies in Poland, Czechoslovakia, Hungary, and the Soviet Union during 1989-91 was thus not simply a ceremonial bow to the orthodox Western doctrine (...) but was interpreted by East European economic transformers. (Bockman and Eyal, 2002: 342)

This interplay between the core authorities and the semi-periphery was also determined by the termination of the dual structure of the external dependency of the former socialist semi-peripheral countries: political dependence on the Soviet imperial center and 
economic catching-up with Western core countries (Böröcz, 1992). In subsequent years after the transition, the core countries, including those from the European Union, aimed to extend their economic influence by integrating new states into political superstructure with its ambivalent system of governance. However, as József Böröcz (2001) argues, it is impossible for the (semi)periphery to take a share in the benefits of this historicaleconomic core position typical for core countries (that is, one fundamentally based on unequal exchange). Prosperity, power and centrality connected to it are admittedly attractive for the semi-peripheral countries, however these countries' catching-up narratives constitute and result from an imitative model of developments, which presents "modernization" as a shared interest. In it, however, "the foreigner of the contiguous peripheries embodies an underdeveloped state of the center's past, and is therefore necessarily inferior” (Böröcz, 2001, p. 35-40).

Thus it is no surprise that Hungary has willingly and successfully aligned with the culture of global capital. Deregulation, privatization, monetarism, and new individualism became parts of the political-economic agenda, planting a specific neoliberal climate in an already particular post-socialist, semi-peripheral context. This climate was characterized by the narratives of catching up with the West: the promises of upward mobility, and mobility toward the core from the periphery. Western values became equivalent with improvement and the Eastern context with decline (Gagyi, 2013). As Wallerstein put it, “[u]nder pressure from core states and putting pressure on peripheral states, their [the semi- 
peripheral countries'] major concern is to keep themselves from slipping into the periphery and to do what they can to advance themselves toward the core" (Wallerstein, 2006: 29).

Despite the promises of the catching-up narrative, because of the historically and economically structural character of unequal exchange, "while exports and imports nearly doubled" during the subsequent period after the transition, "the country's shares in GWP [Gross World Product] remained virtually constant, and at much lower levels than the country's shares in world trade, (...) steep export and import growth failed to generate a growth in GDP relative to GWP" (Böröcz, 2012: 23). Just as 1968 was a symbolic beginning of the disillusionment with the Old Left and 1989 was a "culmination of that disillusionment" (Wallerstein and Dunaway, 1999: 297), the illusions of the revolutionary potential of 1989 also quickly vanished. In 2005 only 14 percent of the respondents said their lives had become easier after the transition (Vásárhelyi, 2005). Expectations of the transition were naïve in all post-socialist countries, but in 1989 there was hope that everything would be better, even if the possible outcomes were not completely unknown. The National Roundtable in Hungary, organized with the intention of laying the foundations of the new order in 1989 , brought attention to the potential social-economic collapse even before the transition. Participants predicted the evaporation of 2 million jobs, the collapse of agriculture, the polarization of society, etc. But the official 
communication that after the transition everything would be better, and the intelligentsia ${ }^{1}$ gave the public very limited information about the estimations, since the question of which economic-political system to choose had already been made. For the elite, the obvious choice was a Thatcherite neoliberal turn. But a huge number of people actually wanted democratic socialism without the Communists (Vásárhelyi, 2005), and even before the transition, "[t]hroughout the 1980s, Eastern Europeans sought to realize nonstate socialisms" (Bockman, 2012). Thus we agree with the interpretation that the National Roundtable was not legitimate in Hungary (Krausz, 2010). However, in 1989 a pre-neoliberal, capitalist, bureaucratic, bourgeois democracy had been established ${ }^{2}$ (Bartha, 2011; Éber et al., 2014; Gille, 2010; Krausz, 2010).

\section{Post-socialist reform package}

Some contend that the transition in education started even before the economic-political transition with the Public Education Act of 1985 (Kozma, 2009a). In these interpretations, the post-socialist history of education is characterized by constant changes between leftist and rightist political regimes after 1989. György Mészáros (2013) argues, though, that the post-socialist history of education is a story of the stabilization of neoliberal

\footnotetext{
${ }^{1}$ The intelligentsia served only as a moral legitimation, since the late-Kádárian technocracy had no moral base and needed legitimation.

2 The transition was in no sense a revolution. As the first democratically elected prime minister, József Antall, said, "You should've made a revolution!"
} 
capitalism and not so much about alternating governments. The Public Education Act was modified in 1993, and the new elite and the experts reached a full consensus on the principles of autonomy, freedom, plurality, and national values. As a result, one of the most decentralized education systems emerged from the gloomy Central-Eastern European semi-periphery, which provided great autonomy for teachers and schools, and supported alternative pedagogies and private institutions. But as an effect of these interventions, the foundations had already been laid for one of the most diverse, vertically and horizontally stratified, and hence extremely selective education systems in Europe, with exemplary diligence in conserving and reproducing social inequalities.

While the elite of the transition and their experts - probably well-intentioned - created the new education system on the basis of freedom in Hungary (...) they in fact set the school to serve the interest of the capital. The ultimate winner of this continuing structure is the capitalist economy and the elite, who have interest in the reproduction of social inequalities. (Mészáros, 2013, p. 87)

The education sector in our "happiest barrack" was already different from those in other Soviet bloc countries before 1989. Decentralization and integration had been on the political agenda since the beginning of the 1970s. In the mid-' 80 s the Hungarian Parliament adopted a law that expanded autonomy and political space for alternative initiatives, thus largely contributing to a diversity of institutions (Halász, 2011). The 1990 reform of the Public Education Act made the establishment of private schools as well as schools set up by foundations possible, and the 1993 reform destroyed the state monopoly on schooling, promoted further decentralization, and created more space for alternative 
solutions and autonomy. This act remained almost unchanged until 2010, since there was a consensus on the basic principles ${ }^{3}$ (Kelemen, 2003; Mészáros, 2013). But this consensus was reached by the elite, the technocracy and the experts. It is not completely true that there was no consultation at all, but subsidiarity has never been a strength of the Hungarian political acropolis. Obviously the idea of self-governing, autonomous schools could have been the first step toward a radical democratic horizontal governance, but the political vacuum after the fall of dictatorial regimes raised the diverse interests of competing groups of experts, technocrats and new policymaking think tanks (Kozma, 2009b). Thus pedagogues could never really become part of the debate about education (Kotasek, 1993) despite the vivid activities of their interest protection groups. While workers' movement and self-management, councils and unions were strengthened and expanded in Hungary throughout the 1980s, Yugoslavia and especially Poland, where "[r]oundtable negotiations between Solidarity and the communist regimes in 1989 reaffirmed the rights of worker self-management" (Orenstein, 2001: 27), the elites weakened the political cooptation of these interest groups after 1989 and "maintained their own power (...) by dislodging and restricting new forms of political representation" (Bockman, 2012: 314).

\footnotetext{
3 These common principles also appeared in the New Education Acts in the Czech Republic and Slovakia in 1990 and in Poland in 1991: the abolition of state monopoly, pluralization, allocation of power to regional authorities, decentralization, autonomy, and authorization of private and religious schools (Kelemen, 2000).
} 
Despite the restrictions, several attempts were made in Hungary to foster debate with the new forms of interest protection groups after 1989. In the 1993 Education Act established new local interest reconciliation bodies and forums (Halász, 2011). But the overall experiences of these attempts at political cooptation were twofold. First, there was a general lack of culture for dialogue because education policy in Hungary was accustomed to central instructions rather than the negotiations with local bodies (Kozma, 2009b). Second, for that reason, the forums' impact fell short of expectations (cf. Halász, 2010). Nevertheless, the political negotiations in the post-socialist acropolis established a laboratory for neoliberal reforms within education from 1989 onward. In the legislative fever, more than 150 government regulations in education were declared from 1990 to 1999 (Kelemen, 2003). Thus, since the mid-1990s teachers have had enough of legislation; they became "sick and tired” of reforms (Halász, 2010; Mészáros, 2013) but not because they thought the education system was at its best. After 2006, teachers were still tired of reforms, but one third of them still thought education needed more reform.

This contradiction between the unbearable reform-dumping and the continuous need for reforms is a basic dichotomy of neoliberalization in education, and not exclusively in Hungary. The key elements of the neoliberal discourse are the narrative of an omnipresent crisis in the education systems and the continuous promotion of the need for reforms and modernization. The neoliberal, "post-socialist education reform package" encompassed 
precisely this sublime dichotomy of the narratives of "crisis," "danger" and "decline" (namely, any deviations from the Western agenda) and the narratives of " 'progress,' 'hope,' and 'salvation,' which the West is inevitably positioned to bring to the newly emerging societies of the post-socialist region" (Silova, 2010: 5-6). In post-socialist, semi-peripheral countries, the promises of education inscribed in "the post-socialist education reform package" ${ }^{4}$ were continuation of the pre- 1989 belief that education is conducive to national growth and, on the other hand, the beginning of (an endless) attempt to catch up with the core countries, where "upward mobility" became a synonym for "development," "progress," "hope," and "salvation" (Hopkins and Wallerstein, 1977). The image of the glorious West, caroling the education gospel (cf. Grubb and Lazerson, 2006), provided the "core" iconography for the re-composition of the education system. Decentralization, marketization, and assessment became the cornerstones of the imaginary catching-up.

Just as the coordination of the transition, the coordination of the implementation of the post-socialist reform package was not constructed solely on the national level. The directions were also determined by international and intergovernmental organizations with strong economic interests (the Organization for Economic Cooperation and Development [OECD], the World Trade Organization, the International Monetary Fund,

\footnotetext{
${ }^{4}$ It is important to note that the post-socialist reform package had a different composition in each country. For example, a full-fledged accountability regime has never been established in Hungary.
} 
the World Bank). In terms of Hungary, the multilateral negotiation with these international organizations was vital to survival because of the drastic fall in GDP after 1989 and the increase of the budget deficit and external debt, which also had a huge effect on education (Halász, 2011). Thus the first decade of the post-socialist era was characterized by bilateral and multilateral negotiations with international organizations, and the outsourcing of the national credits to the international platform (Halász, 2011; Kotasek, 1993; Kozma, 2009b). The establishment of international (inter-)dependency in education were part of the process, in which core groups

manipulate education in periphery nations in order to disseminate ideologies supportive of their interests. From this perspective, international educational 'assistance' projects (...) can be seen as hegemonic ventures dedicated to the engineering of consent in periphery nations to a variety of inequitable and exploitative international structures and relationships." (Clayton, 1998: 484)

In sum, the Hungarian semi-peripheral catching-up revolution thus consisted of stabilizing the core neoliberal hegemony in semi-peripheral education discourse.

But, as discussed above, these processes also contributed to huge inequalities. While the experts believed that the competition between the institutions would contribute to the quality of education, it contributed to huge vertical and horizontal selectivity. Hungary is currently facing the greatest segregation and selectivity an education system can achieve in Europe, reproducing inequalities from a very early age (Mészáros, 2013). Twentyseven years of neoliberal interventions and the incredible amounts of money invested in research and development processes and think tanks have made very little change; 
Hungary is still facing bad cost-effectiveness, fragmented control, no appreciation for teachers, growing inequalities and segregation of Roma children, while the country provides a cheap workforce for multinational corporations in the semi-periphery and in the global auction of workforce.

\section{Neoconservative siege}

Inequalities are, of course, not limited to education. In 2014, almost a million people (counting their families, about 2.5 million) were either registered as public works laborers or as unemployed, passive-unemployed or receiving no aid. While in 2011, 685,000 of the lowest income quintile ( 2 million) were children (under 18), and by 2014 the figure had increased to 800,000 (Ferge, 2008). In addition, in 1990 one of the most enclosed party systems was established in Hungary, and a politico-economic oligarchy of a few hundred thousand people organized as the other (well-off) end of the inequality spectrum. The Hungarian elite became a feudalistic conglomerate with class characteristics: strong economic power characterized by informal connections, and cooperative corruption based on loyalty or friendship (Bozóki and Szalai, 2010). This division of society greatly contributed to what is described above as the continuation of disillusionment after 1989, and to the need for a second, "real" revolution after the promises of 1989 ended in failure. Given the general disillusionment with the (non-existing) Left in Hungary, which "did not seem to end poverty [and] didn't seem to end nondemocratic governments" (Wallerstein and Dunaway, 1999: 297), far-right discourses could gain strong support 
from the public (Szigeti, 2010). This is one reason why a neo-fascist party, Jobbik, received $17 \%$ of the vote in 2010 , when the far-right party Fidesz was voted into power. While the "left wing" tried to dissolve the imperialism of centrum countries in presenting the possible decline, inscribed in national values and the West as the promise of improvement, the right wing dissolved the problem of the national oligarchy by emphasizing national values and promoting confrontation with the "real" sources of the problem: Western liberal imperialists, Roma families and migrants (Gagyi, 2013). This latter discourse seemed to resonate much better with the people's disillusionment.

As Wallerstein argues, the condition of possibility of re-emerging neoconservative discourses is repeated economic downturns, the inevitable crises of capitalism that lead to incredible inequalities. During the downturns, semi-peripheral countries have an increased opportunity to expand their control of their national markets at the expense of core states and to establish new alliances reflected in the increasing degrees of nationalism and militance, while core countries have decreased ability to intervene. During the downturn of production and trade patterns, because of the increased capacity of semi-peripheral countries to act at the expense of core powers,

the indigenous bourgeoisie and the professional strata look upon the state as their negotiating instrument with the rest of the capitalist world-economy $(\ldots)[\mathrm{T}]$ hey are 'nationalist'; that is, they will always be ready to brandish the flag if they believe it has a blackmail effect, and to put the flag in cold storage for a price. (Wallerstein, 1976: 469). 
Just as recently in Poland (cf. Cervinkova, 2016), the spreading neoconservative discourse in Hungary started to form a mixture with neoliberalism from 2010. Wacquant (2012) argues that neoconservatism and neoliberalism tend to come together in the transnational phenomenon in which the "bureaucratic field of the new Centaur state tilts "rightward"' (Bockman, 2012, p. 311). The imagination of strong state and a strong nation, the concept of hard government and a society based on work, combined with nationalist, patriarchal and Protestant morality, are just a few of the directives in the project of neoconservatism.

In 2010 the far-right FIDESZ regime started to implement various neoliberal and neoconservative education reforms: first the centralization and nationalization of the education system; then a teacher appraisal and school inspection system; and finally the inclusion of chauvinist and ethnicist discourses in the national curriculum. We cannot provide here a detailed presentation of these often hybrid (neoliberal and neoconservative) processes because the number of systemic reforms is huge and the 
changes introduced since 2010 are more than eclectic. ${ }^{5}$ Instead, we would like to focus on neoconservatism - the dominant discourse that characterizes the government's interventions.

Since 2010, the government's intention has been to create a strong basis for the rediscovered traditions of authority, control and punishment, and for a mono-cultural ethos of a patriotic establishment addressing the lost prestige of the school and the eroded authority of teachers (Mészáros, 2013). The introduction of a normative value system with the New Education Act in 2010, emphasizing the word "upbringing" instead of "education," was the first step toward a new philosophy of educating "good" citizens. In this new approach, the state is the basis of good education; thus total centralization and control are legitimate per se, just like bringing back the school inspection system, abolished in 1985. The government also makes a strong reference to commonweal as a break with pluralism, presenting education as a public interest for preserving norms and values. These norms and values are often deduced from the Horthy era and characterized

5 To mention just a few changes: the elimination of organizational, professional and economic autonomy; the suspension of quality management; implementation of teachers' external, administrative control; the liquidation of teacher training systems and professional services; the centralization of the curriculum; the elimination of the textbook market and the introduction of new, centrally approved textbooks; the promotion of segregation; the complete shutdown of school improvements; the centralization of the public institutions; the introduction of a compulsory kindergarten from age 3; the reduction of the age limit for compulsory education from 18 to 16; the regulation of the local curricula of schools, which could differ from the state curriculum by only $10 \%$; the introduction of daily physical education. . And this list could continue several pages. 
by the realization of the "fight among nations," and of a need to restore our lost cultural supremacy. In this sense the ultimate purpose of education is the "rise of the nation" (Paár et al., 2011).

It is also important to mention that, just as the Anglo-Saxon model became the main direction in reformulating education policy after 1989, the Hungarian national bourgeoisie has also found a "spiritual" alliance in the recent neoconservative, right-wing, Tory philosophy that has been dominating education reforms in the United Kingdom since 2010. The main criticism addressed the deteriorating quality of schools and the eroded national values (moral atrophy and broken society) in both countries, supplemented with the slogans of "Big Society" in the UK, and the "rise of nation" in Hungary, promoting opportunities and mobility.

While there are obvious similarities in the development of the neoconservative siege in the UK and Hungary, there are also big differences in the implementation. For instance, while centralization - the intention to unify a relatively freely formulated education system - was a process prepared on a long-term basis in the UK, in Hungary it was an accelerated process. Closing and merging institutions in the process of total centralization contributed to the already huge white flight, with more families choosing schools in bigger cities, especially from regions with bigger Roma populations (Magyar Progresszív Intézet, 2012). And while the government in the UK at least intended to make efforts to ensure equal opportunities, in Hungary the intention itself is missing. After centralization, 
the children of the poor still remain in the decaying learning environments of eroding rural or suburban public schools. The increases in the dropout rate and early schoolleavers are already starting to form an army of public-works laborers, whose segregation the government calls segregation "full of love."

Generally speaking, in both Hungary and the UK, the reforms followed the logic of the hybrid and contradictory discourse - neoliberal and neoconservative.

On the one hand, there was the continuing neoliberal emphasis on the minimal state and a belief in the sanctity, efficiency and effectiveness of the market (...) On the other hand, coalition policy 6 was characterized by neoconservatism, evident in the continued central command and control over knowledge and values, and the ongoing mistrust and surveillance of the teacher. (Bailey and Ball, 2016: 128-129)

The rhetorical cornerstones of this political project are the teachers; hence the promise to restore their authority met the government's expectations in terms of getting support from them. But in practice the neoconservative project didn't bring back teachers' prestige and recognition; it only created the panoptical ethos for quality assurance (control and supervision). For instance, a teacher who does not meet the requirements would not accomplish the race to the top inscribed in the new career model, and thus would not be paid more. Moreover, since teachers qualify other teachers, they have been divided into

6 Conservative-Liberal Democrat coalition (2010-15) in Britain and the Alliance of Young Democrats (FIDESZ)-Christian Democratic People's Party (KDNP) coalition in Hungary. 
qualifiers and qualified, surveyors and inspectors. In this process, evaluating teachers became a technique of control and coordination, and the narrative is built on one of the central questions of neoliberalism, namely whether teachers contribute to the country's prosperity. This rhetoric, however, leads to a paradox. It is true that neoliberal discourse pays special attention to the teachers's role, articulating professionalism, selfmanagement and new roles according to lifelong learning. On the other hand, a profile of wage workers emerges from the narratives of the government and the clientele about the "roustabouts of the nation," who are immature or incapable of working autonomously, or of participating in democratic decision-making (Cadiero-Kaplan and Hinchey, 2005). Moreover, teachers in post-socialist countries are facing a general mistrust from the public. Not only did they inherit the distorted image of the servant for indoctrination, but also, in post-socialist neoliberal discourse, society became "oriented to performance, in which individuals strive for their personal growth and self-realization (...) [and] do not see the teaching profession to be sufficiently 'modern,' lucrative and prestigious" (Kotasek, 1993, p. 486). The transition also had a bad effect on teachers in Hungary, whose social and economic appreciation have both been very low since 1989 (Kelemen, 2000). Like other public-sector workers, they are incredibly underpaid. In general, they have been receiving two-thirds of the salaries of their colleagues in the OECD countries. And while on the level of rhetoric the neoconservative siege opposes the neoliberal outburst against the "roustabouts of the nation," in practice it implements "concerted 
attacks on teachers (and curricula) based on a profound mistrust of their quality and commitments" (Apple, 2014: 20).

We should not forget that even though the teachers were sick of reforms, they also became accustomed to an apparent (neoliberalizing) stability of the education discourse. Starting in 2010, this "stability" disappeared, and the climate of uncertainty and authoritarianism started to infiltrate the schools. Teachers' daily struggle became that of developing techniques for survival in the stomach of the bureaucratic giant.

\section{The silence of defense}

Since the Public Education Act was ratified in 2011, the Teachers' Union Strike Committee has been negotiating with the government but has not been able to put pressure on it. But on 5 January 2016, a public letter by the faculty of Herman Ottó High School escalated into an unexpectedly enormous movement (Tanítanék Mozgalom, the "I'd Like to Teach" Movement), and by March 35,000 individuals and 940 educational institutions had joined. The government's first reaction came very soon. On 23 January, Zoltán Balog, Minister of Human Resources, announced the Public Education Roundtable, to which the government invited experts and teachers who met the requirement of minimum loyalty toward the government. A few days later, Balog admitted in an interview that "we pushed the bike too far ... a bit," which meant the government was aware that it had messed up the education system. After this honest admission, dissatisfaction increased. In the meantime, the Teachers' Union organized a demonstration in Miskolc, and solidarity 
demonstrations took place in 10 other cities on 3 February. The Public Education Roundtable's professional credibility was more and more questionable. Many organizations left the table because they thought it was already too late for this kind of negotiation. János Lázár, then Minister of the Prime Minister’s Office, openly responded after the demonstration: "They should negotiate with the government, accept its terms, rather than rebelling against it." The Teachers' Union refused the invitation to the Public Education Roundtable and announced a response in which it argued that the union was "always ready to negotiate, if the partners at the table are equal and not arbitrarily chosen guests who were selected by the government without any consultation, and where the ‘political menu’ is already composed” (Pedagógusok Szakszervezete, 2016).

The tension first peaked on 13 February, when the Teachers' Union and other organizations brought together a huge demonstration. Tens of thousands of teachers, students, healthcare workers and members of various trade unions stood silently in the pouring rain in front of the Parliament building that day. The silence was originated by Mária Sándor, president of the Hungary for the Hungarian Healthcare Sector Civil Association and a prominent figure among protesters for the healthcare sector. Though only five minutes of silence, this moment became the protesters' strongest, most memorable shared experience.

A few weeks later, both the movement's managing body and the Teachers' Union started to elaborate their demands. The Civic Education Platform, founded on 16 February as a 
refusal of government's Public Education Roundtable, released immediate demands: postponement of the Maturity Amendments; immediate suspension of any changes planned by the government in the secondary vocational training system; reduction of academic burdens on pupils; immediate, remedial measures for the equitable and effective care of children with special needs; reduction of the increasing segregation of Roma students; freedom of choice in textbooks; immediate suspension of the teacher qualification and appraisal system; ensuring of the most basic sources for financing education; honest and public communication on education; and development of a new public education system based on achieved results.

However progressive these demands seemed, from this moment the movement went through a complete disintegration, and it finally lost its groundbreaking power. There were two strikes though, on 30 March and 20 April, in different regions. But teacher and children were performing an invisible strike - civic obedience inside the schools. The movement's last event before the summer break was the post-modern Hungarian rhapsody of the grading ceremony on 11 June, when berserk, elated teachers graded politicians from Fidesz, including Prime Minister Viktor Orbán, who received such a huge "picket" - children's slang for the lowest grade in the grading system - that it could not possibly have fit into his schoolbag.

Although many people began to think and talk about the issues of the public sector, the movement's communication was not clear about the directions. The communication was 
divided - a few still urged starting discussions with the government - and the two largest Teachers' Unions (Teachers' Union and Teachers' Democratic Union) continuously competed with each other. The former had more hope in the possibility of negotiating with the government, while the latter demanded more radical steps in enforcing its demands. The general critique of the movement was that it could not use its huge support properly. The movement was unable to form a strong base for social resistance because it remained only in education and intentionally avoided larger political issues.

\section{The convergence of struggles}

In addition to the contradictory character of the hybrid neoliberal and neoconservative politics discussed above - the "tension between a weak but strong state, and between freedom and control, liberty and authority" (Bailey and Ball, 2016: 131) - there is another, crucial paradox. While the conservative turn can be understood as a reaction to what Wallerstein has called the "culmination of disillusionment," the interventions of the neoconservative state also embodied deviations from the Western agenda, described above as the narratives of "crisis," "danger" and "decline" - centralization, control, authority, nationalism, etc. But this paradox is itself a part of the cycles of the worldsystem. As Wallerstein argues, while the

two broad organizing tendencies - that of integrating production on a world-scale and that of forming strong national states - are in principle deeply contradictory, (...) the ever-present tension or antinomy between 
them is one of the perspective's [world-system analysis'] basic, orienting concerns. (Hopkins and Wallerstein, 1977: 113)

We argue, that while the culmination of disillusionment was the condition for the teachers' movement, the danger of deviation from the Western agenda brought back several reflexes, inherited from 1989: precipitance, the lack of social dialogue, uncritical acceptance of Western salvation, and the tremendous influence of experts.

Although the thematic groups in the government's Public Education Roundtable lacked the very core of transparency, the Civic Education Platform (CEP) also built an obscure, top-heavy management structure that was completely in the hands of the experts, those who by hook or by crook were also there during the transition in 1989. As Géza Takács, chief editor of New Pedagogical Review, argued, the real questions in education are the questions of the last 27 years. There is no advocacy or agency for teachers, and the way the CEP was organized is an indicator of this void (Takács, 2016).

In our interpretation, the CEP's and the movement's directives fit into the narrative of the catching-up revolution that characterized the decades after the transition. All the formulated demands (CEP, Teachers' Union, Student Parliament) embraced the policies that encompass a clarified neoliberal future in which Hungary will be closer to the core countries by eliminating the neoconservative interventions. The movement's vocabulary was the same as in 1989: decentralization; autonomy; free choice of schools; political neutrality; and meeting the clientele's needs and the market's demands, combined with equity and social mobility. The reflexes and the vocabulary of the transition came up 
quickly. The power and demands of those tens of thousands of people who stood silently in the rain was allocated to an arbitrarily cobbled Civic Platform, whose task of setting the directives has been again transferred to the same experts from the post-socialist era. There was no evaluation or legitimization of their proposals, which were accepted as the common, mainstream canon. Just as the experts "separated these movements' [social movements, unions, cooperatives during the transition] claims for redistribution, recognition and representation, and selectively enlisted each element, in a limited and distorted way, to legitimate neoliberal capitalism" (Bockman, 2012: 314), the experts of the Civic Platform expropriated the proposals and the vocabulary of the teachers' movement in the same way.

The way the memorable moment of the silence turned into a "schoolish," silly "grading ceremony" is a tragedy and a sign that the movement did not recognize what that silence tried to say. In a small survey, we asked volunteers and activists about their experiences in making that silence speak. The most common answers in terms of what the movement meant to them were "unity is strength"; "we cannot merge all individual aims to one common goal"; "I experienced the potential of joining forces"; "the protest offered community experience, but the rural people and teaching staff still have to be reached and the movement should be more based on dialogue."

Communality, multitude, democracy, dialogue. These are the basic principles we should have learned from global, antisystemic movements, since the globalizing tendencies of 
neoliberal and neoconservative colonization brought demonstrations and protests to life all around the world in recent years, in education as well. ${ }^{7}$ While each and every movement is important, they are often left alone in a social void, but we know about myriad other local actions, trade union collaborations, etc. What we propose here is an approach acknowledging that modern societies should at least recognize the multitude of struggles. In global neoliberal capitalism, the only viable large-scale and long-term movement is one that has the ability to open a common, public space for all possible struggles, with recognizing the possible "convergence of struggles". (cf. Sourice, 2016) Wallerstein argues in a very similar fashion. For him the fundamental strategy of past movements was twofold; namely, to achieve state power and then change the world. However, the fundamental acknowledgement of new social movements is that achieving state power doesn't really change anything, since state power is already constrained by the world-system. Wallerstein argues, that in order to

\footnotetext{
${ }^{7}$ One basis for these protests was the so-called "millennium strikes" in Mexico in 1999, which completely paralyzed the Independent National University for more than nine months. In the mid-2000s, the European Social Forum (ESF) began to function as an organizing force in student movements. The most dominant movements in recent years have been (1) the Chilean student movement against political corruption, (2) the "Indignados" movement in Spain, demonstrations organized by students and their professors against the government's state-controlled test system and (3) the "block book" movement, which aims to connect student movements around the world on a transnational basis (Fernández, 2014; Zolcsák, 2013).
} 
construct workable egalitarian institutions, $(\ldots)[\mathrm{m}]$ ovements need to do a lot more talking to each other, collectively, worldwide. (...) What we need to design is a global "Rainbow Coalition," that is, a confederation of many little movements, representing all kinds of particular grievances, a vast loosely connected movement, without a single organizing theme. (Wallerstein and Dunaway, 1999: 302)

A good example could be the case of the CEU in Hungary, briefly discussed in the introduction, and the protests that it also triggered on the international level. It is crucial to mention, that Hungarians have very limited access to higher education and do research, and the huge inequalities in education also stands at CEU. A vast majority of Hungarian families have either never heard about the university or never considered it as a possibility. The opportunity the CEU provides in Hungary is far from the career prospects of the average Hungarian. Thus the motto of the protest - "the case of the CEU is everyone's case" - is highly problematic. But the very fact that so many people $(80,000)$ went out protesting in April 2017 is magnificent despite the fact that the CEU's case is largely not everyone's case. It is solidarity, alliance and civic support of those people who had really had enough of Fidesz's post-fascist politics. A decisive moment in the future would be come if the protesters and organizers could acknowledge that a convergence of struggles is already inscribed in this mono-themed movement.

In sum, it is important to recognize that education in post-socialist countries is still equivocal with the notions of "progress," "hope" and "salvation," and thus education under relative siege is capable of triggering large protests and laying the foundation of 
new social movements. But it is also crucial to acknowledge that public support of the defense of education reflects people's overall disillusionment in the attempts to catch up with the core countries.

\section{Conclusion}

As we have shown, the political-economic transition in Hungary was in no sense a revolution, but rather a replacement of dictatorial/totalitarian state capitalism with global neoliberal capitalism. The teachers in this gloomy semi-peripheral context (just like some $60 \%$ of the population) were part of the losers in the transition. Any movement that brings back the slogans of the transition has to keep in mind that the words they use are part of the scam of 1989. Instead of focusing on words, we agree with Koczanowicz (2015), who, drawing on Wittgenstein, understands democracy as a "form of life" based on dialogue: that is, understanding instead of consensus. Thus we argue that a movement that fights for democracy must itself become a democratic form of life. Furthermore, Koczanowicz locates the "level zero" state of such a democracy in Mikhail Bakhtin's concept of carnival "as a site of resistance of official political power. (...) Carnival itself, of course, does not contain sophisticated communication, but is a quasi-transcendental condition of such communication" (Koczanowicz, 2015: 80-84).

We argue that the silence on 13 February 2016, was a "level zero" state of democracy. A carnival without the need for words. A moment when everything seemed permitted. A communal performance without boundaries. It created the possibility of a situation "in 
which diverse voices are heard and interact, breaking down conventions and enabling genuine dialogue (...) the chance for a new perspective and a new order of things, by showing the relative nature of all that exists" (Robinson, 2011). The principles of communality, multitude, democracy and dialogue were inscribed in that very moment, just as they were in 1989. But the reflexes of the transition transferred the possibility embedded in the silence into the same processes that have characterized the Hungarian semi-peripheral catching-up revolutions since 1989.

\section{Funding}

The author(s) disclosed receipt of the following financial support for the research, authorship, and/or publication of this article: The authors received funding for this article from Horizon 2020 Framework Programme (Grant / Award Number: 676452).

\section{References}

Apple MW (2014) Official knowledge: democratic education in a conservative 20 age. London: Routledge. Bailey PLJ and Ball SJ (2016) The coalition government, the general election and the policy ratchet in education: a reflection on the 'ghosts' of policy past, present and yet to come. In: The Coalition Government and Social Policy, Policy Press, pp. 127-152.

Bartha E (2011) A rendszerváltás gyermekei. [Children of the Transition.] Fordulat (17): 186-193.

Bockman J (2012) The political projects of neoliberalism. Social Anthropology 20(3): 310-317.

Bockman J and Eyal G (2002) Eastern Europe as a Laboratory for Economic Knowledge: The Transnational Roots of Neoliberalism. American Journal of Sociology 108(2): 310-352. 
Böröcz J (1992) Dual Dependency and Property Vacuum - Social Change on the State Socialist Semiperiphery. Theory and Society 21(1): 77-104.

Böröcz J (2001) Birodalom, kolonialitás és az EU 'keleti bõvítése'. [Empire, colonialism and the EU's 'Eastern Enlargement'.] Replika November(45-46): 23-44.

Böröcz J (2012) Hungary in the European Union: 'Catching Up', Forever. Economic \& Political Weekly 47(23): 22-25.

Bozóki A and Szalai E (2010) A politikai tőke mára súlytalanná vált a gazdasági tőkével szemben. [Political Capital Has Now Become Weightless Than Economic Capital.] Fordulat (14): 28-45.

Cadiero-Kaplan K and Hinchey PH (2005) The Future of Teacher Education and Teaching: Another Piece of the Privatization Puzzle. Journal for Critical Education Policy Studies 3(2): 30-64.

Cervinkova H (2016) Producing Homogeneity as a Historical Tradition. Neo-conservatism, Precarity and Citizenship Education in Poland. Journal for Critical Education Policy Studies 14(3): 43-55

Clayton T (1998) Beyond Mystification: Reconnecting World-System Theory for Comparative Education. Comparative Education Review 42(4): 479.

Éber MÁ, Gagyi Á, Gerőcs T, et al. (2014) 1989. Szempontok a rendszerváltás globális politikai gazdaságtanához. [Considerations for the Global Political Economy of the Transition.] Fordulat (21): 10-63.

Elbert M et al. (1988) Fekete Doboz: Civil Technikák. Hungary: Balázs Béla Stúdió.

Ferge Z (2008) Miért szokatlanul nagyok a magyarországi egyenlötlenségek? [Why are the Inequalities Unusually Large in Hungary?] Esély 20(2): 3-14.

Fernández J (2014) Facing the Corporate-University: The New Wave of Student Movements in Europe. Journal for Critical Education Policy Studies 12(1): 191-213.

Gagyi Á (2013) Az anti-populizmus, mint a rendszerváltás szimbolikus eleme. [Anti-Populism as a Symbolic Element of the Transition.] Fordulat (21): 1-19.

Gille Z (2010) Is There a Global Postsocialist Condition? Global Society 24(1): 9-30.

Grubb WN and Lazerson M (2006) The Globalization of Rhetoric and Practice: The Education Gospel and Vocationalism. In: Lauder H, Brown P, Dillabough J, et al. (eds), Education, Globalization and Social Change, Oxford University Press, p. 298-308.

Habermas J (1990) What does Socialism mean today? The Rectifying Revolution and the Need for New Thinking on the Left. New Left Review 4.

Halász G (2010) Oktatáspolitika az első évtizedben. [Education Policy in the First Decade.] In: Balázs É, Kocsis M, and Vágó I (eds), Jelentés a magyar közoktatásról, Oktatáskutató és Fejlesztő Intézet, 
Budapest, pp. 17-35.

Halász G (2011) Az oktatáspolitika két évtizede Magyarországon: 1990-2010. [Two Decades of Education Policy in Hungary: 1990-2010.] Halász, Gábor, N.d.

Herman Ottó Gimnázium (2016) Nyílt levél a Herman Ottó Gimnáziumból. [Open Letter from Otto Herman Gymnasium.] Borsod Online. Available from: http://www.boon.hu/nyilt-level-a-hermanotto-gimnaziumbol/2982948 (accessed 27 April 2017).

Hopkins TK and Wallerstein I (1977) Patterns of development of the modern world-system. Review 1(2): $111-145$.

Jekel A (2010) Befejezetlen Történet - Antall József halála és a Walt Disney megszakítása. [The Incomplete Story - The Death of Antall József and the interruption of Walt Disney.] Ex Symposion (70): 66-69.

Kelemen E (2000) Oktatásügyi változások Kelet-Közép-Európában az 1990-es években. [Education Changes in Central and Eastern Europe in the 1990s.] Magyar Pedagógia 100(3): 315-330.

Kelemen E (2003) A rendszerváltás és az iskola. [The Transition and the School.] Új Pedagógiai Szemle 53(4): $3-10$.

Koczanowicz L (2015) Politics of Dialogue. Edinburgh: Edinburgh University Press.

Kotasek J (1993) Visions of educational development in the post-socialist era. International Review of Education 39(6): 473-487.

Kozma T (2009a) Kié a rendszerváltás? [Who Owns the Transition?] Educatio 18(4): 423-435.

Kozma T (2009b) Oktatáspolitika-kutatás Magyarországon - A kezdetek. [Education Policy Research in Hungary - The Beginnings.] N.d.

Krausz T (2010) Tézisek a rendszerváltás történeti értelmezéséhez. [Theses for the Historical Interpretation of the Transition.] Eszmélet (88): 80-101.

Magyar Progresszív Intézet (2012) A Fidesz-KDNP igéretei és második Orbán-kormány első másfél éve.

[The Promises of Fidesz-KDNP and the First One and a Half years of the Second Orbán Government.] Magyar Progresszív Intézet.

Méltányosság Politikaelemző Központ (2012) Köznevelés vagy közoktatás? A kormány oktatáspolitikája félidő után. [Government's Education Policy after Half-Time] N.d.: 1-11.

Mészáros G (2013) A közoktatás válsága? Problémák és reformkísérletek kritikai szemmel. [Crisis in Public Education? Problems and Reform Attempts from a Critical Perspective.] Replika 83(2009): $77-91$.

Orenstein MA (2001) Out of the red: building capitalism and democracy in postcommunist Europe. Ann Arbor, MI: The University of Michigan Press. 
Paár Á, Rácz M, Ráski P, et al. (2011) A köznevelés koncepciója és törvényjavaslata. [The Concept and Bill of Public Education.] N.d.

Pedagógusok Szakszervezete (2016) A Pedagógusok Szakszervezetének Közleménye a Miniszterelnökséget Vezető Miniszter „Üzenetéről”. [Communication of the Teachers' Union on the "Message" of the Minister of the Prime Minister.] Pedagógusok Szakszervezete. Available from: http://www.pedagogusok.hu/sites/default/files/a_pedagogusok_szakszervezetenek_kozlemenye_a_ kormany_targyalasi_ajanlatarol-2016-02-11.pdf (accessed 27 April 2017).

Robinson A (2011) In Theory Bakhtin: Carnival against Capital, Carnival against Power. Ceasefire Magazine. Available from: https://ceasefiremagazine.co.uk/in-theory-bakhtin-2/.

Silova I (2010) Rediscovering post-socialism in comparative education. International Perspectives on Education and Society 14(2011): 1-24.

Sourice B (2016) \#NuitDebout: a convergence of struggles takes shape in France. Roar Magazine. Available from: https://roarmag.org/essays/paris-square-occupation-nuitdebout/ (accessed 27 April 2017).

Szigeti P (2010) A magyarországi újkapitalizmus természete és helye a világrendszerben. [The Nature and Place of Hungarian New-Capitalism in the World System] Eszmélet (88): 63-79.

Takács G (2016) A pedagógus-mozgalom folytatódik (?).[The Teacher Movement Continues (?).] ÚJ Pedagógiai Szemle 1-2: 2-4.

Tamás GM (2008) Ellenforradalom az ellenforradalom ellen. [Counter-Revolution Against the CounterRevolution.] Fordulat (2): 6-27.

Vásárhelyi M (2005) Csalódások kora. Rendszerváltás alulnézetben. [Age of Disappointments. Transition from Below.] MTA Társadalomkutató Központ.

Wacquant L (2012) Three steps to a historical anthropology of actually existing neoliberalism. Social Anthropology 20(1): 66-79.

Wallerstein I (1974) The Modern World-System, vol. I: Capitalist Agriculture and the Origins of the European World-Economy in the Sixteenth Century. Academic Press, London.

Wallerstein I (1976) Semi-peripheral Countries and the Contemporary World Crisis. Theory and Society 3: $461-483$.

Wallerstein I (1980) The Modern World-System, vol. II: Mercantilism and the Consolidation of the European World-Economy, 1600-1750. Academic Press, London.

Wallerstein I (1983) Nationalism and the World Transition to Socialism: Is There a Crisis? Third World Quarterly 5(1): 95-102. 
Wallerstein I (2006) World Systems Analysis: An Introduction. Duke University Press, Durham and London.

Wallerstein I and Dunaway WA (1999) Crisis, Transition, and Resistance Movements: A Conversation with Immanuel Wallerstein. Appalachian Journal 26(3): 284-305.

Zolcsák A (2013) A chilei diákmozgalom. [The Chilean Student Movement.] Eszmélet 25(100): 186-195. 